\title{
Individual choice and unequal participation in higher education
}

\author{
Kristin Voigt
}

Final version published in Theory and Research in Education 2007, 5(1), 87-112.

\begin{abstract}
Does the unequal participation of non-traditional students in higher education indicate social injustice, even if it can be traced back to individuals' choices? Drawing on luck egalitarian approaches, this paper suggests that an answer to this question must take into account the effects of unequal brute luck on educational choices. I use a framework based on expected utility theory to analyse qualitative studies on educational choice. This reveals a variety of mechanisms through which differences in background conditions make non-traditional students less likely to apply to university and/or particular institutions; the unequal participation of non-traditional students in higher education remains a problem of social justice.
\end{abstract}

KEYWORDS: higher education; equality; egalitarianism; choice.

\section{Introduction}

It is an important consideration of social justice that class and ethnic background should not affect individuals' chances of going to university. While in the UK, the current expansion of post-compulsory education is accompanied by an emphasis on increasing participation by non-traditional students ${ }^{1}$, their representation in higher education remains problematic. While young adults from ethnic minorities are now more likely to go to university than their white counterparts, they primarily attend 'new' institutions, which are considered to be less prestigious (Modood, 2006). Students from lower socio-economic groups remain under-represented in the higher education section as a whole ${ }^{2}$, and this under-representation is particularly pronounced at the more prestigious universities ${ }^{3,4}$. To the extent that this is the result of bias or discrimination on part of institutions, this is clearly an injustice ${ }^{5}$. However, we know that a significant proportion of this underrepresentation is due to the choices that members of these groups make: many decide not to apply to university, and when they do apply, they tend to choose less prestigious 
universities. The question I address in this paper is whether the under-representation of non-traditional students in (parts of) the higher education sector is problematic from the point of view of social justice, even if it is the result of individuals' choices.

To address this question, we must establish what role individual choice should play in legitimising unequal outcomes. The idea that choice must play a pivotal role in generating just outcomes is taken up by luck egalitarianism, a recent theory of equality. Luck egalitarians use the familiar distinction between 'choice' and 'circumstance' to draw the line between just and unjust inequalities: inequalities resulting from circumstances beyond an agent's control are unjust and must be rectified, while inequalities resulting from individuals' choices are justified. On this approach, then, it might seem that self-selection in the realm of higher education, because it is based on individuals' choices, is not morally problematic. However, as I argue in this paper, this impression is mistaken. Luck egalitarians must take seriously the idea that brute luck affects the choices people make, and these effects are particularly obvious when we look at the decision making processes of potential higher education applicants from different social groups. An analysis of the qualitative research reveals the significant impact unequal background conditions have on the choices of potential applicants from different groups, making it less likely that "nontraditional' applicants apply to prestigious universities, or even apply to university at all. Even where the resulting under-representation is due to individual choice, these choices are not sufficient to legitimise the inequalities emanating from them.

The paper begins by introducing the luck egalitarian approach and outlining its implications for the question of higher education choices (section 2). Section 3 introduces a framework for thinking about individual choices, based on the expected utility model developed by rational choice theorists. Drawing on qualitative studies, I assess the conditions under which young adults make their educational choices. This assessment 
reveals the impact of a wide range of factors which systematically make higher education and/or particular institutions a less appealing option for non-traditional students. These choices, then, cannot legitimise the unequal outcomes they generate and the resulting under-representation of certain groups in higher education remains a concern from the point of view of social justice. Section 4 concludes by indicating possible policy implications ${ }^{6}$.

\section{A luck egalitarian approach to educational choice}

Luck egalitarianism is a prominent contemporary theory of social justice, associated with theorists such as Richard Arneson (1989, 1990), G. A. Cohen (1989, 2004) and Ronald Dworkin $(1981,2000,2002,2003)^{7}$. According to luck egalitarianism, distributions should reflect the choices that it is reasonable to hold agents responsible for, while the differential effects of 'brute luck' must be compensated for'.

It remains controversial how we are to draw the line between 'choice' and 'luck', and under what conditions it is reasonable to hold individuals distributively responsible ${ }^{9}$ for the choices they make. At first glance, the luck egalitarian approach might seem to support the idea that where people choose not to go to university, any disadvantages they face as a result of that decision are just. However, we know that unequal brute luck affects the conditions under which people make their choices; where this is the case, it becomes problematic to let them bear the full costs of those choices ${ }^{10}$.

When applied to higher education choices, this approach creates a difficulty. Greater academic talent makes it more likely that an agent will choose to pursue higher education. However, to the extent that talent is affected by luck, this influence is just as problematic as the effect of other factors beyond individual control, such as class background: 'Luck egalitarians have no immediate interest in reducing the net effect of class background if that means increasing the effect of other morally arbitrary characteristics - even where these are 
quite properly regarded as "merit"” (Swift, 2005: 267). The luck egalitarian approach, then, does not support a meritocratic approach to education; from the luck egalitarian perspective, it would make far more sense to regard education as a resource that should be distributed so as to address differences in ability ${ }^{11}$. This idea, of course, runs counter to the common intuition that talent must be an important factor in allocating university places.

Similarly, the luck egalitarian approach cannot capture the intuition that parents' buying a superior education for their children, through private schooling or private tuition, is unfair while more talented children having greater chances of success is not. The luck egalitarian cannot make a morally relevant distinction between genetically determined talent and the advantages some parents can provide for their children: both are a matter of luck and neither can give rise to justified inequalities on the luck egalitarian approach. I cannot respond to this problem here. Instead, I focus on class and ethnic background as obvious instances of unequal luck whose influence on higher education access is widely regarded as problematic from the point of view of social justice.

\section{The elements of individual choice}

This section aims to identify inequalities in the context within which individuals from different social and ethnic backgrounds make educational choices. I use a framework based on the expected utility model to identify four factors pertinent to individual choice. This allows us to think about individual choice in a more structured way and to assess the impact of unequal background conditions on all of these four factors.

Expected utility theory is based on the idea that from a set of available options, agents choose the one that maximises expected utility, as derived by multiplying the utility of a certain outcome and its associated probability. Expected utility theory has been criticised for a number of reasons ${ }^{12}$. One problem particularly relevant in the present context is that 
interview data about people's decision-making processes conveys a far more complex picture of individual choice. Choices reflect individual aspirations, anxieties, personal attachments and other factors that standard expected utility theory does not consider. Furthermore, real-life situations rarely allow agents to carefully consider all options available to them and to collect exhaustive information about the costs and benefits associated with each of them. Instead, 'decision making is often a messy process in which intuition, affective response and serendipity can play a greater role than rational calculation and systematic evaluation of the evidence available' (Reay et al., 2005: xi). Similarly, Hodkinson and Sparkes describe the decision-making processes of the subjects in a study on pupils' occupational choices as

pragmatic, rather than systematic. They were based on partial information located in the familiar and the known. The decision-making was context-related, and could not be separated from the family background, culture and life histories of the pupils (Hodkinson and Sparkes, 1997: 33).

However, we can, at least to some extent, integrate this criticism into the model by reinterpreting the values in the expected utility equation as subjective, rather than objective, and by including more 'emotional' considerations (e.g. whether someone would enjoy higher education) as costs or utilities. This provides a more realistic understanding of individual decision-making while enabling us to give structure to our thinking about these choices. With these considerations in mind, we can identify four elements of individual choice. I draw on empirical evidence to illustrate the ways in which these are affected by unequal background conditions ${ }^{13}$.

According to expected utility theory, the expected utility of an option consists of the utility associated with each outcome within that option and its associated probability. This approach allows us to identify three main elements of a person's choice. First, people 
choose from an available option set. Second, the available outcomes are associated with certain probabilities and, third, utilities ${ }^{14}$. However, a fourth factor should be added to this framework. Agents must decide on the basis of what they perceive option sets, probabilities and utilities to be; information is crucial in making these estimations. It is important to take this factor into account because gathering information is costly, and because uncertainty can make options less attractive to the agent. Problems relating to the amount and quality of information available to agents will therefore be considered separately.

\subsection{Options}

The first element in choice is the range of options available to the agent. Circumstances beyond agents' control can affect the range of available options in ways that make it unfair to let them bear the full costs of their choices. Option sets can be made unequal for example by the presence of formal barriers to entry to higher education. Where members of certain ethnic groups are restricted from entering university, the option of higher education is thereby removed from the option set. At least in the UK, such restrictions are not in place and so higher education is an option objectively available for everyone.

However, taking account of the subjective aspect of individual choice, the situation appears more complicated. An option can feature in the agent's decision only if she is aware of this option being available to her. The qualitative research, however, suggests that agents are often unaware of educational options that would lead to social destinations very remote from their social origins. Louise Archer, for example, notes that for the workingclass students in her study, 'the possibility of going to university was a "non-choice", it had not entered their choice/decision-making horizon' (Archer, 2000: 5). Similarly, students from middle-class backgrounds typically state that they 'have never really considered dropping out of school and getting a job' (quoted in Ball et al., 2000: 71), suggesting that 
they saw university 'as the "obvious" way forward... Their choices would focus on what to study and where to apply, rather than if application should be made at all' (Pugsley, 1998: 73). These studies convey the impression that students' family background creates an environment of 'implicit assumptions and expectations' (Hutchings and Archer, 2001: 71) that makes certain choices 'invisible' (Pugsley, 1998: 74). For example, in a study that asked participants to list higher education institutions according to desirability, middleclass students did not include the 'newer' and presumably less prestigious universities among their lists: 'The New Universities are not rejected as possibilities, they do not even enter into consideration. They are inconceivable' (Ball et al., 2002a: 68).

That educational choices can lack the appearance of 'actual' decisions is reflected in statements such as the following, made by a middle-class student explaining why she chose to go to university:

I never thought that I wouldn't go to university... all the way along, it never entered my head that I wouldn't go to university... I don't think we really thought about it at Dame Margaret's, most people assumed they would go on... I don't know if we ever really discussed it (quoted in Power et al., 2003: 84).

Why do certain options fall off students' decision-making 'horizons' in this way? Research suggests that family background plays a considerable role in this process. Middleclass students in particular were acutely aware of what educational decisions their parents wanted them to take, and often stated that it had not occurred to them to deviate from these expectations: "Embedded perceptions and expectations make certain choices "obvious" and others unthinkable, according to where you stand in the overall landscape of choice' (Ball et al., 2002a: 58).

Options must also be regarded as achievable possibilities: educational choices involve 'not only identifying "the best" but having the confidence to regard it as within reach' 
(Power et al., 2003: 83). Different studies reflect that this is frequently not the case for working-class students. For example, working-class students often thought that the qualifications to enter higher education would be prohibitively high; '[h]igher than Einstein', and certainly 'higher than [the ones] I have' (quoted in Hutchings and Archer, 2001: 74).

Schools make a significant difference here. Reay et al. suggest that private schools are shaped by 'a culture of entitlement; an implicit assumption of compatibility in relation to Oxbridge' (Reay et al., 2005: 48), while no such culture could be detected in state schools or inner-city schools examined in other studies (Archer and Yamashita, 2003).

The under-representation of certain groups in higher education itself could contribute to differences in subjective option sets. Archer and Yamashita (2003) describe the experience of a black teacher at an inner-city school, who recalls that one black student remarked, 'you're the first Jamaican I've seen wearing a suit', and suggest that ' $[\mathrm{t}]$ he boys' unfamiliarity with everyday examples of local black men in professional ("suit") jobs helps place these aspirations out of the realm of everyday reality/possibility' (Archer and Yamashita, 2003: 62).

It seems, then, that unequal background conditions can reduce individuals' subjective option sets even if objectively more options are available. From a luck egalitarian perspective, this means that the choices made are insufficient to justify the unequal outcomes resulting from them.

\subsection{Probabilities}

The second element of individual choice are the probabilities agents associate with certain outcomes; in the present context, the relevant probabilities are those of succeeding 
or failing on a particular educational path. These probabilities can, of course, be affected by factors that agents cannot be held responsible for.

One example here is the anticipation of discrimination against certain groups, which reduces the chances of success for members of the affected groups. Where individuals think that because they belong to a certain group, they will be discriminated against - for example when applying to a particular university - their subjective probabilities of success are reduced and they are for that reason less likely to apply to the institution in question. The anticipation of rejection is reflected in different studies where potential applicants expressed fear of discrimination on grounds of school background, region (Connor and Dewson, 2001) and ethnicity (Archer 2003: 128) if they were to apply to prestigious universities ${ }^{15}$.

Social beliefs and stereotypes can also affect expectations of success in a less direct way, by leading to poorer performance by the targets of such stereotypes. This can affect educational choices because students often rely on past performance (as indicated by grades, test results, etc.) as an indicator of academic ability and future performance. Social psychologists suggest that in situations where individuals face a 'stereotype threat' (i.e. they are the target of a negative group stereotype and are in a situation where their actions might confirm this stereotype), their performance is likely to be poorer than it would be in the absence of such a threat. In experiments involving standardised tests, for example, participants from low class backgrounds performed worse than participants from higher class backgrounds when the test was presented as a measure of verbal ability; when the test was not presented as a measure of ability, performance of lower class participants matched that of the higher class participants (Croizet and Claire, 1998). Similar findings were made with respect to the performance of African-Americans (Steele and Aronson, 1995) and women (Spencer et al., 1999). 
Economic factors also play a crucial role in raising subjective chances of success. Some parents have the financial means to provide additional support for their children, resulting in higher grades, which then feed into decisions about higher education. For example, Reay et al. find that over $25 \%$ of the private school students in their study received private tuition, compared to $10 \%$ of state school pupils (Reay et al., 2005: 87).

Some parents will also be able to send their children to private schools, which can provide a wide range of other advantages for their pupils that are beyond the reach of most state schools. Power et al. note that

The 'success' of the private sector does not necessarily, and certainly not simply, reflect a greater capacity to 'bring out the best' in academically able pupils. It also reflects a concerted drive to channel students into high-status universities by encouraging high aspirations and discouraging less 'ambitious' choices, having special provision for potential Oxbridge entrants and sometimes having detailed knowledge of and actual contacts with particular colleges (Power et al., 2003: 90).

Reay et al. confirm the connections between private school teaching staff and Oxbridge; $24 \%$ of the staff at the private school in their study were Oxbridge graduates (Reay et al., 2005: 48). To the extent that access to private schools is based on parents' ability and willingness to pay the required fees, this is an obvious problem of social justice ${ }^{16}$.

Students from poorer backgrounds can also expect their academic performance to be affected by the amount of part-time work necessary to meet their day-to-day expenses; this is an experience many students make while working for their A-levels and again at university. Reay et al. (2005: 86) report significant differences in the amount of part-time employment pupils from different social backgrounds were undertaking. At university, part-time employment is a necessary source of income for many students (Smith and Taylor, 1999: 148). That part-time employment can exert significant pressure on students 
and make it harder for them to succeed is clear from the qualitative data. One student describes her situation:

I cried about my financial situation in class this morning because it is too much. It is very very difficult financially. Sometimes I need to go to the library but I don't want to walk and honestly I don't have the bus fare to go and so it is really affecting my studies at the moment because I can't afford to do anything and you think the course will not cost any money but then you need books and pens and writing paper (quoted in Reay et al., 2005: 89) $)^{17}$.

\subsection{Utility and costs}

A further aspect of educational choices are the utility and costs associated with certain options. Qualifications can lead to higher earnings but are obtained at a cost: the opportunity cost of earnings foregone while in education as well as any direct costs associated with the educational option in question. These costs, however, may have different implications for students from different backgrounds. Furthermore, we must also take into account non-monetary costs and benefits, such as the experience of higher education itself.

Consider first monetary costs. Educational options are frequently associated with direct costs such as tuition fees. A certain absolute 'price', however, may translate into different 'costs' for people from different backgrounds. A certain cost may involve a significant sacrifice for some families but be only a minor financial restriction on others, given differences in wealth and income. Furthermore, income insecurity remains higher in lower social classes, making it reasonable for them to be more cautious when making investments in their children's education (Goldthorpe, 1996). This means that even where students face the same absolute costs of education, students from low-income backgrounds are 
disadvantaged relative to their wealthier peers and less likely to pursue higher education.

The extent to which financial constraints restrict individual choice is well illustrated by the 'localism' (Reay et al., 2001: 861) characterising the narratives of working-class students: only 41\% of the working-class students in Reay et al.'s (2005: 86) study were considering moving out of their parents' home, compared to $70 \%$ of the middle-class students. Travel costs were a significant factor in the choices of many working-class students, 'delineating the possible from the impossible' (Reay, 2003: 61):

We need to study close to home because you've got to look at the economic situation. I mean we're not middle-class in the way that a lot of people can just go to any university they want, far from home (quoted in Reay, 2003: 61).

To some extent, costs can be met through student loans. There are, however, classspecific differences in attitude to debt. Several studies suggest that 'debt aversion is a class issue. Students from poorer backgrounds are more debt averse than those from other social classes' (Callender and Jackson, 2005: 535) ${ }^{18}$. The estimated increase of student debt to an average of $£ 15,000$ for students entering higher education in 2006/07 (DfES, 2003b) can be expected to be a greater deterrent for students from lower class backgrounds.

We might argue that the degree of debt aversion displayed by working-class students is irrational, especially if the income threshold for repayment is very high. The greater debt aversion among low-income groups, however, makes more sense when considered in the context of their different financial experience. Callender and Jackson suggest that the attitude to debt displayed by low-income students could be considered as rational given that 'we are now asking them to borrow more money than their parents may earn in a year' (Callender and Jackson, 2005: 535). Nonetheless, if the repayment threshold was very high, the risk associated with student debt would be diminished to an extent where it would indeed seem irrational not to take advantage of it. 
However, it is not unreasonable to argue that if this phenomenon can be explained by the differential financial experience shaping low income applicants' attitudes to debt, the luck egalitarian case is not significantly diminished by the rationality or otherwise of such debt aversion: if the high debt aversion of low-income applicants is the result of the experience of growing up in a low-income family, then this should be regarded as a result of unequal background conditions and for that reason problematic from the point of view of equality.

A related problem is that of students who object to student loans for religious reasons, such as religious Muslims who are reluctant to take out loans on which interest is paid. How religious commitments should feature in the luck egalitarian account is still a matter of debate ${ }^{19}$ but it is reasonable to think that a society unwilling to cater for such beliefs is 'ethnocentric' and 'indirectly discriminat[ing]' against certain groups (Callender, 2002: 89).

What about the monetary benefits of higher education, the higher incomes made possible by a degree? While many non-traditional students saw higher education as 'an almost mythical ticket to social mobility and a good life' (Archer and Hutchings, 2000: 565), they also emphasised the job insecurity in a labour market perceived as overcrowded with graduates:

All this money innit is really not worth it because at the end of the day you could get your degree and all that and you can't get a job you're sweeping the streets with your degree! So what's the point?! (quoted in Archer and Hutchings, 2000: 567)

That many non-traditional students perceive only the less prestigious institutions as attainable for them (if they think of higher education as an 'option' at all), has important implications here because these applicants felt that such institutions would provide qualifications that are not valued by employers:

The way I think they do it is they take all the application forms and they put them into 
piles so its [sic] like Oxford, OK that goes in one pile, they might see North London, that goes in one pile... and then they start off... OK let's look at this Oxford lady first... and I think that's why a lot of people even though with university degrees, they have to wait so long before they can finally get a proper job (quoted in Archer 2003: 130).

The restricted subjective option set that we noted in section 3.1 includes only options that are perceived as providing relatively small returns; this, of course, makes higher education a far less attractive option (see also Archer 2003: 129-30).

Some decision theorists suggest that agents evaluate potential outcomes relative to their current position: potential outcomes are perceived as losses or gains, rather than in absolute terms (Kahneman and Tversky, 1979). This idea is taken up by a number of sociologists who suggest that the potential benefits of education are evaluated with reference to current class positions (e.g. Becker, 2003; Breen, 2001; Esser, 1999; Goldthorpe, 1996). Furthermore, these authors suggest that the negative impact of downward social mobility features more strongly in agents' decisions than the positive implications of upward mobility:

[Y]oung people have, as their major educational goal, the acquisition of a level of education that will allow them to attain a class position at least as good as that of their family of origin... their chief concern is to avoid downward mobility (Breen, 2001: 1; see also Breen and Goldthorpe, 1997).

This assumption, which finds support in empirical studies (e.g. Davies et al., 2002; Lucey and Reay, 2002), implies that higher education is more attractive for middle-class students, who need a degree to maintain their parents' class position, than it is for workingclass students, for whom a degree is not necessary in this way. Working-class students, furthermore, face a greater risk of status decline in case of educational failure because working-class parents have fewer resources to support their children if they fail. 
However, it is not only financial considerations that feature in educational choices; nonmonetary costs and benefits play a crucial role. A first factor are the social implications of certain choices. Education is an important determinant of social destinations, and educational choices reflect concerns about the social positions that will be made available or precluded by certain decisions. Attaining higher education is commonly seen as a way of maintaining, or gaining, middle-class status. For middle-class students, this implies continuity with their current class identity; for working-class students, however, participation in higher education leads to conflict with prior social identifications: they are 'educating [themselves] out of their class' (Reay et al., 2005: 93). Lynch and O'Neill explain that

[W]orking class people who succeed in the education system have to abandon certain features of their background class habitus (that is, their modes of thought, perception, appreciation and action...) in a way that is not really true for other socially mobile groups. ... Their defining identity in social class terms is automatically changed by virtue of their educational success... working class people exercise a structural relationship to education which is fraught with dilemmas and contradictions... (Lynch and O’Neill, 1994: 318) ${ }^{20}$.

This, of course, creates an immediate inequality: working-class students regard higher education as a disruption of their class identity, a break with their background and are likely to experience a sense of 'dislocation' and of being a 'misfit' (Reay 1997: 21). This cost of higher education characterises working-class students' choice, while no such factor exists for the middle-class students:

The risks and reflexitivity of the middle classes are about staying as they are and who they are. Those of the working classes are about being different people in different places, about who they might become and what they must give up (Ball et al., 2002a: $69)$. 
Closely related to this is that, for working-class students, moving up the social 'ladder' implicit in getting a degree creates a 'social distance' from a network of friends and relatives (Akerlof, 1997: 1006). Social mobility disrupts relationships individuals have; for middle-class students, for whom higher education represents continuity with their existing class identity, this cost will be much smaller.

Particularly worrying is that some non-traditional applicants' evaluation of different institutions involves a devaluation of their own background. Ethnic minority and workingclass applicants often rule out universities that are perceived as particularly 'ethnic' or 'working-class'. One black student explains,

I've sort of avoided all the universities with lots of black students, because they're all the universities which aren't seen as so good. If you're black and not very middle class and want to do well then you end up choosing places where people like you don't go and I think that's difficult (quoted in Reay, 2003: 54).

Similarly, a working-class applicant on an Access scheme notes that 'the kind of place that would have accepted me isn't the kind of place that I would have wanted to go' (quoted in Reay et al., 2001: 867).

Another important factor are the expectations potential applicants have of what being at university is like. Working-class and ethnic minority students often perceive higher education as an alien environment. This is important with respect to whether or not higher education is pursued at all, but also with respect to choice of institution. One working-class student explains:

I don't seen the point in spending my time with people who are not going to be able to relate to me and I'm not going to be able to relate to them. We are from different worlds, so I think I've had enough of that in my life ... I don't want to feel as if I have to pretend to be someone I'm not (quoted in Reay, 2001: 337) ${ }^{21}$. 
Students from ethnic minority backgrounds often point to the 'whiteness' of prestigious universities: 'we've always had the impression it [Oxford] was just like for white people ... the prospectus it's like white people' (quoted in Hutchings and Archer, 2001: 82). Similarly, Ball et al. (2002a) interviewed a black student, whose choice of institution involved research on the kind of ethnic 'mix' she would be able to expect there:

I did read about the African Caribbean Societies and the Asian societies and all the different things they do, and I know there are quite a few people, a few black people and Asian people who go to Sussex and Manchester Met and stuff like that and that was important that they had those sorts of societies there. It means you know you're not going to be the only black person there ... I prefer to be somewhere where there is different cultures. And so I did make sure that there was a mix... (quoted in Ball et al., 2002a: 56$)^{22}$.

Working-class students typically describe higher education, and in particular the more prestigious institutions, as a culture dominated by 'middle-classness', where they would be alienated and unable to connect (Lynch and O'Riordan, 1998). Very clear in this respect were working-class students' perceptions of more traditional universities. One student recounts his experience of an admissions interview at Cambridge:

It was a complete shock, it was different from anywhere else I have ever been, it was too traditional, too old fashioned, from another time altogether. I didn't like it at all. It was like going through a medieval castle, when you were going down the corridors. The dining room was giant long tables, pictures, it was like a proper castle, and I was thinking - where's the moat, where's the armour? Save me from this. You know, you expect little pictures with eyes moving around, watching you all the time. And I just didn't like the atmosphere, not one bit... All typical private school, posh people... posh and white (quoted in Ball et al., 2002a: 68).

A similar experience is recounted by a working-class student who was interviewed at 


\section{Goldsmiths':}

The interview was like what I imagined to be a conversation around a dinner table in like a real upper-class, middle-class family, about world politics and I was like, oh my God, I'm not ready for this. This is not for me. It was terrifying. I was thinking oh my God, I'm not good enough to be coming here (quoted in Reay, 2001: 339).

Students explicitly reject certain institutions on the basis of the perception that they would not fit in - 'what's a person like me going to do at a place like that' (quoted in Reay et al., 2005: 91) - instead looking for universities that provide an environment in which they expect to feel 'comfortable' and 'at home' (Raey et al., 2005: 91), even if these institutions are much further down on the league tables; universities are 'good' if they are seen as 'the right place for me' (quoted in Reay et al., 2005: 91):

UCL is wonderful, but it's a very rich university. Not really my sort of place. LSE was another that I sort of thought I couldn't really apply to ... They seem to be one of the best so there's an element of will I fit in somewhere like UCL and LSE. I think you have to suit somewhere that suits you. I didn't want to go to a really snobby university. ... I'm not interested in the best universities. It's more a case of what's the best university for me (quoted in Reay, 2001: 338).

Even among middle-class students, in particular those from state school backgrounds and those from families with little or no history of higher education, there are similar perceptions of prestigious universities, which are seen as populated by over-confident public school students:

I wouldn't choose Durham again. Well I chose it purely because it was considered the next best university but it was full of people from private schools and it's just completely different. They were amazing these people. They all had dads who were head of maths and they'd all been through private school, and had their little cliques and not my thing really (Power et al., 2003: 97-98). 
All of these factors increase the costs and decrease the utility working-class and ethnic minority students associate with higher education in general and/or particular institutions and make these far less attractive options than they are for their white, middle-class peers.

\subsection{Information and uncertainty}

Expected utility theory assumes that agents know the likelihoods with which particular events will occur. This assumption will obviously not hold for most real-life choices, where agents face what decision theorists call uncertainty or ambiguity. Ambiguity relates to a perceived or actual lack of information or knowledge on part of the agent. The effects of both information and ambiguity on higher education choices are discussed in this section.

The qualitative data reveals a significant asymmetry in information about various aspects of higher education; while some applicants have access to a wealth of formal and informal information through family, peers or schools, many non-traditional applicants lack access to such information. This information asymmetry entails unequal costs for applicants from different groups: unlike applicants with families, peers and/or schools that provide the relevant information, students who lack these informational resources must seek out and acquire the required knowledge. Gaining information is costly in many ways: it is timeconsuming, often requires financial resources and it can induce anxiety and insecurity. These factors - clearly matters of circumstance - make it less likely that students from nontraditional backgrounds will apply to university.

The empirical research suggests significant disparities in information about higher education between students, varying in particular with family background and type of school attended (Ball et al., 2002a: 69). This leads to a situation in which 'much of what needs to be known is taken for granted, by the middle class, but it needs to be discovered by, or explained to, the working class family' (Pugsley, 1998: 81). This uncertainty is also 
reflected in the students' experiences of their decision making process:

I realise now that I don't even know what most of the colleges do. It really is difficult making sensible decisions, you know, when you only have patches of information. I realise now that I didn't even know the questions to ask. It's terrible (quoted in Ball et al., 2000: 28).

Power et al. find that students with a family history of higher education and those from schools with strong records in higher education progression made accurate predictions of the relative prestige of different universities (Power et al., 2003: 87; also Ball et al., 2002a). One middle-class mother's description of her child's knowledge of higher education institutions makes clear that such knowledge is almost intuitive:

In a sense he just knew which the best ones were. And it wasn't the league tables. It's just the sense of the university, the location, the history and just a kind of knowing that people just do know what's good (quoted in Reay et al., 2005: 67).

This contrasts markedly with the account of a working-class student in the same study: Socially, or through my family, I don't know anybody who has completed university. My uncle was the first person in my entire family, like, ever, to go to university and complete it, but he died in 1993, so I don't know, I didn't really have time to talk to him about it, or find out anything or get any encouragement, advice or anything like that from him. So I suppose that's maybe why I didn't know about the reputations of the universities or any sort of things like that. Apart from what I was told by the prospectuses, the brochures, computers, what my teachers told me. I sort of worked it out as I went along really, played it by ear. Maybe if I had known some people that had gone to university it might have made my choices different, or maybe not, I don't really know (quoted in Reay et al., 2005: 30).

There are also clear differences in the kind and quality of information and advice provided by schools. Private schools provide a variety of information for their students, 
which contrasts markedly with the situation at state schools, where pupils received little information about higher education, and what advice they did receive was often seen as 'largely uninfluential, or, at times, actively unhelpful' (Reay et al., 2005: 39).

Potential applicants' knowledge about the costs of higher education was also skewed. The working-class students in Hutchings and Archer's (2001) study agreed that the cost of going to university would be very high (also Connor et al., 1999) but had little knowledge of the exact costs. Similarly, Connor and Dewson (2001: 55-6) find that non-traditional entrants lacked information about the sources of support available to them and how they could access them. Hutchings and Archer (2001: 77) report that none of their respondents mentioned means-testing in this context ${ }^{23}$.

Students themselves expressed the uncertainty created by a lack of information about higher education caused by their families' lack of experience with it:

I did make the decision on my own, God, it sounds like - yeah, my parents had nothing to do with it. I mean, they did, but the way I look at it, it sounds terrible, but my parents, because the thing is my parents let me do what I want to do, it's not like they are letting me go wild, but they want me to choose what I want to choose. They haven't been to university themselves so they don't know a lot about which are the best places to go to. My dad says 'its [sic] up to you'... (quoted in Reay et al., 2005: 65).

Even middle-class students whose families had no history of higher education recount similar experiences:

[The parents] haven't been. It's only because they haven't been themselves, so it would be wrong for me to expect them to be able to help me. They wouldn't really be able to help me in terms of universities, simply because they haven't gone. But they keep telling me to go, and apart from that they can't help me that much, I don't think (quoted in Reay et al., 2005: 76). 
A teacher explains:

An awful lot of our parents haven't been to university themselves and they tend to leave it to their children to sort out, with help from the school of course. There's definitely no three way dialogue... it's more a case of students informing their parents rather than asking them for advice (Reay et al., 2005: 65).

Parents with higher education experience can provide their children with the kind of information and advice about universities, student life and the application process that students with no family history of higher education (both in working and middle-class) lack. It is also significant that it is the absence of this kind of personal, 'hot' (Ball and Vincent, 1998) knowledge that working-class students experience as debilitating.

Lack of information about how best to secure access to higher education can also lead students to make choices that, in retrospect, turn out to be disadvantageous. One workingclass student recounts his choice of A-level subjects:

Like I just went up there [the FE college] and said, 'I want to do some A levels' and they said 'alright what do you want to do?' and that was it really. It was only later I realised that the university wasn't going to look at me if I was only doing Art and that, I needed to swap to do English and Sociology as well to go on, but by that time it was too late in the year so I started again and it's better now. But they never said nothing before like (quoted in Pugsley, 1998: 78).

Information asymmetries can, of course, be diminished by students' attempts to gather the relevant information. This process, however, involves costs of different kinds. First, significant sacrifices of time are necessary to find out about different institutions, the application process, the relevant financial arrangements, etc. Second, much inside knowledge can be gained only at significant financial expenditure; for example, visiting different university sites and attending Open Days can be very helpful, but these are costly 
undertakings. One teacher at a state school explains that even when the school offered to cover half of the costs of visiting universities, pupils could not afford to attend the visit: students haven't got the money to do that. Parents haven't got the money to be able to send them on a trip and it's a big, big problem for many of our students. So although there have been trips available the uptake has been low. Even the Sussex trip... I mean, it wasn't expensive, it was seven pounds, but still for some students that's unmanageable (quoted in Reay et al., 2005: 147).

Finally, for many non-traditional applicants the process of gathering information creates a lot of anxiety. As one student explains,

Yes, it's been really, really difficult. It ended up being very stressful because I was doing it in such a void. I'd got no idea of how much was involved, that there was such an enormous number of universities to choose from and that you could end up making some really stupid mistakes. It's been really scary thinking that you could have made the wrong decisions, very anxiety inducing. I know so little about it all and my family know nothing about it so it was a big thing finding out everything for yourself. So I did find it very stressful not knowing how to go about it, not really knowing what to look for. I mean school helped quite a lot but basically it's your life and that's quite scary thinking you could mess it up because you don't know enough (quoted in Reay, 2003: 54).

Due to unequal brute luck - in particular, parents' history of higher education and schools - some applicants have little information about higher education, while such information is readily available to others. While non-traditional applicants may, of course, acquire the relevant knowledge, this requires significant sacrifices of time, money and mental energy. These costs themselves will make the pursuit of higher education a less attractive option for non-traditional applicants.

The experimental data on decision theory allows us to speculate that there will be further 
effects created by unfamiliarity with higher education. Agents seem averse to uncertainty: in experimental settings, agents are more likely to choose gambles that involve known probabilities, even where there is no reason to assume that the odds of the uncertain bet are inferior $^{24}$. What exactly ambiguity is, is contentious, but according to one definition, it is the 'subjective experience of missing information relevant to a prediction' (Frisch and Baron, 1988: 152).

It seems reasonable to extrapolate from this that agents are less likely to pursue vague or unfamiliar options than options that involve familiar or known areas. What this means for the present context is that potential university applicants are more likely to pursue educational or vocational paths with which they are familiar. Sources of familiarity are, of course, factors such as family experience, peer group contacts and school environment: young adults, then, are more likely to pursue paths that resemble those of their parents, an effect which is moderated - or reinforced - by peer group and school influences.

Experimental data suggests that ambiguity aversion is reinforced by different choice contexts. Heath and Tversky (1991) suggests that we are averse to options about which we feel relatively incompetent. Fox and Tversky (1995) find that agents are reluctant to act on what they perceive as inferior knowledge. This effect is reinforced when an unfamiliar option is assessed at the same time as an option about which the agent has more knowledge, or when she compares her level of competence with the superior knowledge of other agents. Within the context of higher education choices, these effects are likely to come into play when non-traditional applicants perceive their lack of familiarity with higher education relative to other occupational paths and relative to traditional applicants. For traditional applicants, on the other hand, the same effects will make decisions in favour of higher education more likely. 


\section{Conclusion}

This paper considered the persisting under-representation of non-traditional students in (parts of) the higher education sector from the point of view of social justice. I asked whether the fact that much of this under-representation is due to individual choice makes the inequalities arising from it unproblematic from the point of view of social justice. I considered this question against the background of luck egalitarian theory, which focuses on the distinction between chance and choice to decide whether or not inequalities are justified. For the luck egalitarian, however, the presence of choice is not enough to legitimise unequal outcomes; we must also take account of how these choices are influenced by factors beyond agents' control. The paper focuses on the impact of class and ethnic background on educational choices. The empirical data suggests that educational choices reflect the inequalities against which they are made. We can identify a variety of mechanisms which tend to make higher education and/or particular institutions less attractive for working-class and ethnic minority students (and in some contexts middleclass students with no family history of higher education) than they are for white middleclass students (with a family history of higher education). This is not to say, of course, that these choices are entirely a matter of unequal brute luck. However, given the significant impact unequal background conditions have on the educational choices young people make, these choices cannot legitimise the inequalities emanating from them; the underrepresentation of non-traditional groups in higher education remains problematic from the point of view of social justice.

To conclude, I want to highlight briefly a few policy implications of this argument. First, consider the costs of higher education. As I explained, these costs translate into higher 'real' costs for students from low-income groups. This makes tuition fees problematic but maintenance costs are already enough of an obstacle for many working-class students. To 
minimise the impact of financial considerations, applicants from low-income backgrounds would have to be supported through grants to cover both maintenance and fees. Such support would have to take the form of grants to counteract the debt aversion of workingclass students but also as a matter of equality ${ }^{25}$ : as long as we cannot prevent more advantaged parents from paying for their children's degrees, equality requires that we compensate those students whose families are unable to do this. Even then, however, students from low-income backgrounds face a disadvantage in having to acquire the relevant information about, and applying for, financial support.

Second, higher education policy cannot be isolated from the structure of primary and secondary schooling. It is hard to see how fair access to higher education can be made consistent with private schooling as it exists in the UK. Private schools provide many advantages for their students, ranging from information about higher education to personal contacts with Oxbridge colleges. Even within the state sector, middle-class parents are in a better position to avoid poorer schools, for example by moving into the catchment area of 'better' comprehensives (Archer and Yamashita, 2003; Reay, 2004).

Finally, the assumption that higher education choices are merely 'investment decisions' and that even non-traditional students will apply to higher education if they realise the benefits outweigh the costs, is over-simplistic. Such a view makes it too easy to forget that higher education is riskier, more costly and less beneficial and hence a far worse 'investment' for non-traditional students than it is for their middle-class peers. While it is true that many non-traditional students do not conceive of higher education as a possible option, the suggestion that their aspirations must be 'corrected', that they must 'aim higher', is highly problematic. It implies that non-traditional applicants' decision to abstain from higher education reflects their 'faulty' preferences, thus locating the source of the 'problem' in the individual; instead, the argument presented here implies that the 
preferences of traditional and non-traditional applicants can, and must, be understood within the context in which they are formed; what needs 'correction' are the structural inequalities that make higher education an easy, attractive option for some while placing it (almost) out of reach for others.

\section{Acknowledgements}

I am grateful to Adam Swift for detailed comments and helpful discussions of earlier drafts of this paper. I would also like to thank the referees for Theory and Research in Education for their suggestions. 


\section{Bibliography}

Akerlof, G. (1997) 'Social distance and social decisions'. Econometrica 65(5): 1005-1027. Archer, L. (2000) Social Class and Access to Higher Education: A Report on the Findings from the Social Class and Widening Participation to HE Project, University of North London. London: Institute for Policy Studies in Education.

Archer, L. (2003) 'The "value" of higher education', in L. Archer, M. Hutchings and A. Ross, Higher Education and Social Class: Issues of Exclusion and Inclusion, pp. 119-136. London: RoutledgeFalmer.

Archer, L. and Hutchings, M. (2000) “'Bettering yourself”? Discourses of risk, cost, and benefit in ethnically diverse, young working-class non-participants' constructions of higher education'. British Journal of Sociology of Education 21(4): 555-573.

Archer, L. and Yamashita, H. (2003) “"Knowing their limits"? Identities, inequalities and inner city school leavers' post-16 aspirations'. Journal of Education Policy 18(1): 53-69.

Arneson, R. J. (1989) 'Equality and equal opportunity for welfare'. Philosophical Studies 56: 77-93.

Arneson, R. J. (1990) 'Liberalism, distributive subjectivism, and equal opportunity for welfare'. Philosophy and Public Affairs 19(2): 158-194.

Ball, S. J. and Vincent, C. (1998) "I heard it on the grapevine": "hot" knowledge and school choice'. British Journal of Sociology of Education 19(3): 377-400.

Ball, S. J., Maguire, M. and Macrae, S. (2000) Pathways and Transitions Post-16: New Youth, New Economies in the Global City. London: Routledge.

Ball, S. J., Davies, J., David, M., Reay, D. (2002a) "Classification" and "judgement": social class and the "cognitive structures" of choice of higher education'. British Journal of Sociology of Education 23(1): 51-71.

Ball, S. J., Reay, D. and David, M. (2002b), “Ethnic choosing”: minority ethnic students, social class and higher education choice'. Race, Ethnicity and Education 5(4): 333-357.

Becker, R. (2003) 'Educational expansions and persisting inequalities of education: utilizing subjective expected utility theory to explain increasing participation rates in upper secondary school in the Federal Republic of Germany'. European Sociological Review 19(1): 1-24.

Boliver, V. (2004) 'Widening participation and fair access at the University of Oxford', Sociology Working Paper, Department of Sociology, University of Oxford.

Breen, R. (2001) 'A rational choice model of educational inequality', Instituto Juan March Working Paper, 166 (October).

Breen, R., and Goldthorpe, J. H. (1997) 'Explaining educational differentials: towards a formal Rational Action Theory'. Rationality and Society 9(3): 275-305.

Bridges, D. (2006) 'Adaptive preference, justice and identity in the context of widening participation in higher education'. Ethics and Economics 1(1): 15-28.

Brighouse, H. (1995) 'In defence of educational equality'. Journal of Philosophy of Education 29(3): 415-420.

Brighouse, H. (2000) School Choice and Social Justice. Oxford: Oxford University Press.

Callender, C. (2002) 'The costs of widening participation: contradictions in New Labour's funding policies'. Social Policy \& Society 1(2): 83-94. 
Callender, C. and Jackson, J. (2005) 'Does the fear of debt deter students from higher education?'. Journal of Social Policy 34(4): 509-540.

Callender, C. and Kempson, E. (1996) Student Finances: Income, Expenditure and Take-up of Student Loans. London: Policy Studies Institute.

Camerer, C. and Weber, M. (1992) 'Recent developments in modeling preferences: uncertainty and ambiguity'. Journal of Risk and Uncertainty 5(4): 325-70.

Cohen, G. A. (1989) 'On the currency of egalitarian justice'. Ethics 99(4): 906-944.

Cohen, G. A. (1999) 'Multiculturalism and expensive tastes', in R. Bhargava, A. K. Bagchi and R. Sudharshan (eds.), Multiculturalism, Liberalism and Democracy, pp. 80-100. New Delhi and Oxford: Oxford University Press.

Cohen, G. A. (2004) 'Expensive taste rides again', in J. Burley (ed.), Dworkin and His Critics, pp. 3-29. Oxford: Blackwell.

Connor, H. and Dewson, S. (2001) Social Class and Higher Education: Issues Affecting Decisions on Participation by Lower Social Class Groups, Research Report 267 (London: DfEE).

Connor, H., Burton, R., Pearson, R. Pollard, E. and Regan, J. (1999) Making the Right Choice: How Students Choose Universities and Colleges. London: Institute of Employment and CVCP.

Croizet, J. C., and Claire, T. (1998) 'Extending the concept of stereotype threat to social class: the intellectual underperformance of students from low socioeconomic backgrounds'. Personality and Social Psychology Bulletin 24(6): 588-594.

Davies, R., Heinesen, E. and Holm, A. (2002) 'The relative risk aversion hypothesis of educational choice'. Journal of Population Economics 15(4): 683-713.

DfES (2003a) The Future of Higher Education, Cm5735. Department for Education and Skills.

DfES (2003b) 'Student loans and the question of debt', available online at http://www.dfes.gov.uk/hegateway/uploads/Debt\%20-\%20FINAL.pdf.

Dworkin, R. (1981) 'What is equality? Part 2: Equality of resources'. Philosophy and Public Affairs 10(4): 283-345.

Dworkin, R. (2000) Sovereign Virtue: The Theory and Practice of Equality. Cambridge: Harvard University Press.

Dworkin, R. (2002) 'Sovereign Virtue revisited'. Ethics 113(1): 106-143.

Dworkin, R. (2003) 'Equality, luck and hierarchy'. Philosophy and Public Affairs 31(2): 190-198.

Dworkin, R. (2004) 'Ronald Dworkin replies', in J. Burley (ed.), Dworkin and His Critics, pp. 339-395. Oxford: Blackwell.

Ellsberg, D. (1961) 'Risk, ambiguity, and the Savage axioms'. The Quarterly Journal of Economics 75(4): 643-669.

Elster, J. (1983) Sour Grapes: Studies in the Subversion of Rationality. Cambridge: Cambridge University Press.

Esser, H. (1999) Soziologie: Spezielle Grundlagen, Band I: Situationslogik und Handeln. Frankfurt: Campus Verlag.

Fox, C. and Tversky, A. (1995) 'Ambiguity aversion and comparative ignorance'. The Quarterly Journal of Economics 110(3): 585-603. 
Frisch, D. and Baron, J. (1988) 'Ambiguity and rationality'. Journal of Behavioral Decision Making 1(3): 149-157.

Galindo-Rueda, F., Vignoles, A. F. and Marcenaro-Gutier, O. (2004) The Widening SocioEconomic Gap in UK Higher Education. Centre for the Economics of Education Discussion Paper, London School of Economics.

Gambetta, D. (1987) Were They Pushed Or Did They Jump? Individual Decision Mechanisms in Education. Cambridge: Cambridge University Press.

Goldthorpe, J. (1996) 'Class analysis and the reorientation of class theory: the case of persisting differentials in educational attainment'. British Journal of Sociology 47(3): 481505.

Heath, C. and Tversky, A. (1991) 'Preference and belief: ambiguity and competence in choice under uncertainty'. Journal of Risk and Uncertainty 4(1): 5-28.

Hodkinson, P. and Sparkes, A. (1997) 'Careership: a sociological theory of career decision making'. British Journal of Sociology of Education 18(1): 29-44.

Hutchings, M. and Archer, L. (2001) "Higher than Einstein": constructions of going to university among working-class non-participants'. Research Papers in Education 16(1): 69-91.

Kahneman, D. and Tversky, A. (1979) 'Prospect theory: an analysis of decision under risk'. Econometrica 47(2): 263-292.

Kymlicka, W. (1996) Multicultural citizenship: a liberal theory of minority rights. Oxford: Oxford University Press.

Leathwood, C. (2004) 'A critique of institutional inequalities in higher education (or an alternative to hypocrisy for higher educational policy'. Theory and Research in Education 2(1): 31-48.

Leathwood, C. and O'Connell, P. (2003) "'It's a struggle": the construction of the "new student" in higher education'. Journal of Education Policy 18(6): 597-615.

Lucey, H., Melody, J. and Walkerdine, V. (2003) 'Uneasy hybrids: psychosocial aspects of becoming educationally successful for working-class young women'. Gender and Education 15(3): 285-299.

Lucey, H. and Reay, D. (2002) 'Carrying the beacon of excellence: social class differentiation and anxiety at a time of transition'. Journal of Education Policy 17(3): 321336.

Lynch, K. and O’Neill, C. (1994) 'The colonisation of social class in education'. British Journal of Sociology of Education 15(3): 307-324.

Lynch, K. and O'Riordan, C. (1998) 'Inequality in higher education: a study of class barriers'. British Journal of Sociology of Education 19(4): 445-478.

McManus, I. C., Richards, P., Winder, B. C., Sproston, K. A. and Styles, V. (1995) 'Medical school applicants from ethnic minority groups: identifying if and when they are disadvantaged'. British Medical Journal 310: 496-500.

Mendus, S. (2002) 'Choice, chance and multiculturalism', in P. Kelly (ed.), Multiculturalism Reconsidered, pp. 31-44. Cambridge: Polity Press.

Miller, D. (2002) 'Liberalism, equal opportunities and cultural commitments', in P. Kelly (ed.), Multiculturalism Reconsidered, pp. 45-61. Cambridge: Polity Press.

Modood, T. (1993) 'The number of ethnic minority students in British higher education: 
some grounds for optimism'. Oxford Review of Education 19(2): 167-182.

Modood, T. (2006) 'Ethnicity, Muslims and higher education entry in Britain'. Teaching in Higher Education 11(2): 247-250.

Power, S., Whitty, G., Edwards, T. and Wigfall, V. (2003) Education and the Middle Class. Buckingham: Open University.

Pugsley, L. (1998) 'Throwing your brains at it: higher education, markets and choice'. International Studies in Sociology of Education 8(1): 71-92.

Quong, J. (2006) 'Cultural exemptions, expensive tastes, and equal opportunities'. Journal of Applied Philosophy 23(1): 53-71.

Reay, D. (1997) 'The double-bind of the "working-class" feminist academic: the failure of success or the success of failure?', in C. Zmroczek and P. Mahoney (eds.), Class Matters: Working Class Women's Perspectives of Social Class, pp. 18-29. London: Taylor \& Francis.

Reay, D. (2001) 'Finding or losing yourself? Working-class relationships to education'. Journal of Education Policy 16(4): 333-46.

Reay, D. (2003) 'Shifting class identities? Social class and the transition to higher education', in C. Vincent (ed.), Social Justice, Education and Identity, pp. 51-64. London: Routledge.

Reay, D. (2004) 'Exclusivity, exclusion, and social class in urban education markets in the United Kingdom'. Urban Education 39(5): 537-560.

Reay, D., David, M. and Ball, S. J. (2005) Degrees of Choice: Social Class, Race and Gender in Higher Education. Stoke on Trent: Trentham Books.

Reay, D., Davies, J., David, M., and Ball, S. J. (2001) 'Choices of degree or degrees of choice? Class, "race”, and the higher education choice process'. Sociology 35(4): 855-874.

Roemer, J. E. (1993) 'A pragmatic theory of responsibility for the egalitarian planner'. Philosophy \& Public Affairs 22(2): 146-166, reprinted in his Egalitarian Perspectives: Essays in Philosophical Economics. Cambridge: Cambridge University Press.

Roemer, J. E. (1998) Equality of Opportunity. Cambridge, Mass.: Harvard University Press.

Roemer, J. E. (2000) 'Equality of opportunity', in K. Arrow, S. Bowles and S. Durlauf (eds.), Meritocracy and Economic Inequality, pp. 17-32. Princeton: Princeton University Press.

Scanlon, T. M. (1986) 'Equality of resources and equality of welfare: a forced marriage?'. Ethics 97(1): 111-118.

Schoemaker, P. J. (1982) 'The expected utility model: its variants, purposes, evidence and limitations'. Journal of Economic Literature 20(2): 529-563.

Shiner, M., and Moodod, T. (2002) 'Help or hindrance? Higher education and the route to ethnic equality'. British Journal of Sociology of Education 23(2): 210-232.

Smith, P. and Taylor, N. (1999) "“Not for lipstick and lager": students and part-time work'. Scottish Affairs Journal 28: 147-63.

Spencer, S. J., Steele, C. M., and Quinn, D. M. (1999) 'Stereotype threat and women's math performance'. Journal of Experimental Social Psychology 35(1): 4-28.

Steele, C. M., and Aronson, J. (1995) 'Stereotype threat and the intellectual test performance of African Americans'. Journal of Personality and Social Psychology 69(5):797-811. 
Swift, A. (2003a) How not to be a Hypocrite: School Choice for the Morally Perplexed Parent. London: Routledge.

Swift, A. (2003b) 'Seizing the opportunity: the influence of preferences and aspirations on social immobility'. New Economy 10(4): 208-212.

Swift, A. (2004a) 'Would perfect mobility be perfect?'. European Sociological Review 20(1): 1-11.

Swift, A. (2004b) 'The morality of school choice'. Theory and Research in Education 2(1): 7-21.

Swift, A. (2005) 'Justice, luck and the family: the intergenerational transmission of economic advantage from a normative perspective', in S. Bowles, H. Gintis and M. A. Osborne Groves (eds.), Unequal Chances: Family Background and Economic Success, pp. 256-276. Princeton: Princeton University Press.

Vallentyne, P. (2002) 'Brute luck, option luck, and equality of initial opportunities'. Ethics 112(3): 529-557.

\footnotetext{
1 See, for example, DfES (2003a).

${ }^{2}$ Galindo-Rueda et al. (2004) suggest that over three quarters of students from professional backgrounds and only $14 \%$ of those from unskilled backgrounds study for a degree.

3 See Boliver (2004) for data from Oxford University.

${ }^{4}$ It is important to consider not just the participation of non-traditional students in the higher education sector as a whole but also how non-traditional students are represented at different institutions, not least because within a highly hierarchical higher education sector such as the UK's, a degree from a 'traditional' university tends to be of greater value in the labour market than one from a 'new' institution; choice of institution therefore has direct implications for the kinds of benefits graduates can expect from their degrees. For a discussion of the inequalities within the UK higher education sector, and how it reflects and contributes to social inequality, see Leathwood (2004).
}

5 Research suggests that discrimination on part of institutions may still be a problem, especially for ethnic minority candidates. For example, in their study on admission to medical school, McManus et al. (1995) find that ethnic minority candidates are discriminated against on the basis of their surnames. Shiner and Modood (2002) suggest that pre-1992 institutions discriminate against ethnic minority candidates, while the 'new' universities display a bias in favour of candidates from ethnic minority groups.

6 The empirical evidence used in this paper is drawn primarily from the UK context, where a growing body of qualitative studies gives us important insights into the decision-making processes of (potential) higher education applicants from different backgrounds. However, unequal higher education participation is a common phenomenon in many countries, and the approach developed in this paper could also be applied to empirical evidence from other contexts.

7 However, Dworkin has rejected the label 'luck egalitarian' for his theory (Dworkin 2003: 190-1).

${ }^{8}$ Luck egalitarians rely on the distinction between 'brute' and 'option luck': while option luck refers to risks an agent 'should have anticipated and might have declined' (Dworkin 1981 [2000: 73]), brute luck cannot be avoided in this way. Different interpretations of the distinction are discussed by Vallentyne (2002).

9 The notion of responsibility used here is the kind of responsibility relevant to questions of social justice, which may differ from other kinds of responsibility, such as moral responsibility.

10 Roemer suggests that we can determine the extent to which people should be held responsible for their choices by comparing the decisions they made to those of agents who are situated similarly with respect to brute luck factors. This approach is applied to education in Roemer (1993; 1998: ch.9; 2000).

11 Brighouse (1995) suggests this as an understanding of equal educational opportunity in the context of compulsory education; a more detailed discussion of how the notion of equality should be interpreted within the context of schooling can be found in Brighouse (2000).

12 For an overview of how actual choices systematically deviate from the predictions of expected utility theory, see Esser (1999) and Schoemaker (1982). 
13 Gambetta's (1987) study also draws on rational choice theory in evaluating the educational choices of students from different backgrounds but while he analyses statistical data, I draw on qualitative studies to evaluate the impact of background conditions on educational choices.

14 There are two different ways of conceptualising the relationship between available options and costs associated with them. Consider a situation where someone can pursue a certain option for free, while for a second agent, it is associated with a certain cost. On the approach adopted in this paper, we would describe this situation by saying that the option in question is available for both, but that the second agent can pursue it only at the specified cost. We could, however, also incorporate the cost in the description of the option so that we would say that a particular course of action, 'pursuing the option in question for free', is available to the first agent, but not the second. The second approach allows us to describe the situation in the language of equal opportunities: agents are facing unequal option sets and thus unequal opportunities. The first approach does not have the same immediacy but it allows us to capture several other inequalities in background conditions that are not easily described in terms of unequal opportunities.

15 It is important to note here that what matters from the point of view of individual decision making is whether agents think that they will be discriminated against, whether or not this is in fact the case.

16 That the UK private sector for secondary schooling allows children from privileged backgrounds to jump the 'queue' for university, is one of Swift's arguments against private education (Swift, 2003a, 2004b).

17 See also Leathwood and O'Connell (2003: 608).

18 See also Callender and Kempson (1996), Hutchings and Archer (2001).

19 Kymlicka (1996) defends his equality-based argument for minority rights with reference to Dworkin's approach but, as Cohen (1999) points out, Dworkin's account of responsibility, which is tied to agent identification, would not yield these results. See also Cohen $(1989,2004)$, Dworkin $(2000,2004)$, Mendus (2002), Miller (2002), Quong (2006) and Scanlon (1986).

20 See also Reay (2001), Lucey et al. (2003).

21 This phenomenon is sometimes interpreted as an example of 'adaptive preferences' or 'sour grapes' (Elster, 1983), whereby working-class students lower their aspirations in response to the (perceived) unattainability of higher education. However, to what extent these preferences are 'adaptive' is difficult to assess. Moreover, arguably all preferences, including those of middle-class students, adapt to circumstances (see Bridges, 2006). What creates the injustice in the present context is not that working-class students' preferences are adaptive whereas those of middle-class students are not; rather, what is creating the injustice is that agents' preferences adapt to very different sets of (perceived) opportunities (see also Swift, 2003b, 2004a).

22 Ball et al. (2002b) provide a more detailed analysis of the role 'ethnic mix' plays in the educational choices of ethnic minority applicants.

23 The fact that more advantaged families can finance their children's higher education without taking out loans is again relevant here because it means that there is a wealth of complicated information that students from more advantaged backgrounds do not even have to consider.

24 This phenomenon is known as the Ellsberg paradox (Ellsberg, 1961) but more recent studies have found the same effect; see Camerer and Weber (1992) for an overview.

25 The present concern is how financial support for higher education would have to be structured to minimise the unequal impact tuition fees have on applicants from low income backgrounds. There may, however, be reasons of justice to require graduates to repay (some of) the financial support they have received while in higher education. 